[Running head: Child Labor and Rainfall Deviation]

\title{
CHILD LABOR AND RAINFALL DEVIATION: PANEL DATA EVIDENCE FROM RURAL VIETNAM
}

\author{
TRONG-ANH TRINH, AlberTO POSSO, ${ }^{*}$ AND SiMON FEENY \\ International Development and Trade Research Group, School of Economics, \\ Finance and Marketing, RMIT University, Melbourne, Australia
}

First version received June 2018; final version accepted August 2019

\begin{abstract}
Rainfall shocks to the agricultural sector can pull children into agricultural work and/or household chores. This is problematic because both forms of child work are potentially precarious. This study examines the relationship between rainfall deviations and child labor for rural households in Vietnam using panel data covering the period 2006-14. We classify child labor into agricultural and nonagricultural activities as well as household chores. We study children's entrance into work and the time intensity of work. Using child-level fixed effects, we find evidence that above-average rainfall is associated with children entering agricultural work as well as being pulled into (and spending more time doing) household chores. Our findings suggest that intra-household experiences of exogenous weather shocks are likely to vary at the individual level, suggesting a need for a more tailored approach to policymaking.
\end{abstract}

Keywords: Weather shocks; Child labor; Agriculture; Vietnam

The authors are thankful to David Soler Crespo, Joseph Gomes, Alex Armand, and other participants of the Navarra Center for International Development Seminar Series. We also thank Jacobus de Hoop, Stephen C. Smith, Jose Cuesta, and two anonymous reviewers for valuable comments.

* Corresponding author: Alberto Posso, 440 Elizabeth Street, Melbourne VIC, Australia, 3000. Email: alberto.posso@rmit.edu.au

This is the author manuscript accepted for publication and has undergone full peer review but has not been through the copyediting, typesetting, pagination and proofreading process, which may lead to differences between this version and the Version of Record. Please cite this article as doi: 10.1111/deve.12215 
JEL classification: O15; J13; O53 


\section{INTRODUCTION}

Rainfall shocks in the agricultural sector have an ambiguous effect on child labor. On the one hand, above-average rain might lead to increased agricultural productivity and an increase in demand for all types of labor, including that of children. On the other hand, the exogenous deviation in rainfall could provide sufficient income for households to meet their minimum substance requirements without the use of child labor. ${ }^{1}$ In this scenario, potentially, the positive shock pulls adult workers into agriculture, but not children. As adults get pulled into agriculture, however, they are likely to leave a gap in other activities, including household chores and nonagricultural production. If children and adult workers are substitutes (Basu and Van 1998), then it is likely that this gap is filled by children. Consequently, a rainfall shock may lower child labor in some activities while increasing it in others.

These channels are important because while child labor in agriculture is understood to often include precarious activities, increasingly it is also recognized that household chores, undertaken by children in their own homes, might interfere with their education or be excessive (ILO 2018). Moreover, there are several identified hazards to which domestic workers, including children, are particularly vulnerable, such as the use of toxic chemicals, carrying heavy loads, handling dangerous items such as knives, axes and hot pans, or sometimes suffering humiliating or degrading treatment (ILO 2018). Therefore, rainfall deviations leading to agricultural productivity shocks that substitute children out of one type of work and into others may still prove problematic.

This study explores the empirical relationship between exogenous agricultural productivity shocks and child labor using panel data from rural Vietnam. Agricultural productivity shocks are proxied with rainfall deviations measured as the difference between actual and historical rainfall. Rainfall shocks are chosen because they are considered both exogenous to production processes and are highly relevant in Vietnam, which is amongst the five most vulnerable economies to climate change in the world (World Bank 2010). Similarly, child labor remains important in Vietnam with approximately one in 10 Vietnamese children aged 5-17 currently working (ILO 2015).

\footnotetext{
${ }^{1}$ This concept is theoretically developed in Basu and Van (1998).
} 
We use data from the younger cohort of the Young Lives Project, which provides a panel of children aged 4-13 over the period 2006-14. We decompose child labor into (1) agricultural work; (2) nonagricultural work (making and selling handicrafts / piece work and / or carrying bricks or working in factories); and (3) household chores to get a comprehensive view of how households allocate child labor. These data are coupled with rainfall deviation, calculated as the difference between rainfall over the last three months and its historical average over 15 years. Deviation over a three-month period is chosen because rice crops (the most common product in Vietnam) usually reach maturity at around 90 days after crop establishment, while the interview date falls during a typical period for rice harvesting. ${ }^{2}$

There is a very large literature on household income shocks and child labor. Our work is closely linked to a smaller field of study that focuses on the nexus between exogenous shocks to the agricultural sector and child employment. Dammert (2008) studies the effect of the "air-bridge" denial policy, which reduced exports of coca plants between Peru and Colombia in 1995. She notes that the subsequent fall in household income of coca growers resulted in increases in work hours of children living in coca-growing states. Beegle, Dehejia, and Gatti (2006) and Gubert and Robilliard (2008) test the relationship between child labor and the value of crop loss due to insects, rodents, and other calamities. They find that child labor increases when there is an unexpectedly poor harvest, and that child labor declines as the household recovers from this negative shock. Colmer (2013) looks at the relationship between the coefficient of variation in rainfall and child labor in Ethiopia. He finds that climate variability increases the number of hours spent on farming activities and reduces the number of hours spent on domestic chores.

This study builds on these papers with several important contributions. First, we exploit the availability of panel data more comprehensively than previous studies by using a child-level fixed effects strategy that allows us to control for unobserved time-invariant child characteristics that can potentially influence the household's child labor decision. This departs from the existing literature which mostly includes household (Beegle, Dehejia, and Gatti 2006; Gubert and Robilliard 2008) or village (Colmer 2013) fixed effects. This means

\footnotetext{
${ }^{2}$ Harvesting activities include cutting, stacking, handling, threshing, cleaning, and hauling. Good harvesting methods help maximize yield and minimize damage and deterioration.
} 
that results of changes in coefficients are interpreted as being associated with within child changes. Second, we follow Dammert (2008) and examine if weather shocks impact on different types of child labor. As discussed above, we apply a comprehensive decomposition of work into chores (within the home), farming, and non-farming activities. Finally, our empirical approach focuses on whether rainfall deviations are associated with (1) entrance or exit into different types of work as well as (2) the amount of time that working children dedicate to work activities. Therefore, the study aims to understand if weather shocks influence children's entrance into a work activity as well as the intensity in which the working child practices this activity.

The rest of the paper is structured as follows. Section II presents the data. Section III discusses the empirical approach, while Section IV reports the results. The final section concludes.

\section{DATA}

We collect monthly rainfall data from the Gridded Monthly Time Series (version 4.01) (GMTS) developed by the Centre for Climatic Research, University of Delaware. This dataset contains global historical estimates of temperature and rainfall for a grid of 0.5 degree by 0.5 degree of latitude and longitude, where the grid nodes are centered on 0.25 degree. Each grid covers an area of 50 square kilometers. We match grid data to household data at the commune level, averaging 36 square kilometers, using the four closest grid points in GMTS. Since grids cut across communes, one commune might incorporate multiple grids. Where this is the case, an average of the rainfall from these grids is calculated to obtain commune-level rainfall while accounting for the portion of each grid covered by the commune. Average rainfall at the commune level is used to define a rainfall shock as below:

$$
R D_{i, t}=R_{i, t}-\overline{R_{i}},
$$

where $R D_{i, t}$ is rainfall deviation at time $t$ and $R_{i}$ is actual rainfall in the commune where child $i$ lives three months before the interview date (Mendelsohn, Nordhaus, and Shaw 1994; Boozer and Suri 2001; Deschênes and Greenstone 2007; Trinh 2017). The term $\overline{R_{i}}$ is 
historical average rainfall in the same commune calculated over a 15 -year period. ${ }^{3}$ Figure 1 reveals that above-average rainfall is prevalent in the Central and Southern regions, while below-average rainfall is more common in the North. In the five provinces covered by the Young Lives survey, Lao Cai has the highest deviation of rainfall, followed by Da Nang and Phu Yen.

\section{[Figure 1 here]}

Information on child labor and household characteristics are derived from different rounds of the Young Lives Longitudinal Survey. We use available panel data from Vietnam covering the period 2006-14. The Young Lives sampling approach is based on a sentinel site surveillance system with the sample divided into smaller clusters. Two groups are followed: 2,000 children born in 2001-2 (the young cohort) and 1,000 children born in 1994-95 (the old cohort). The first round of data collection took place in 2002, followed by the second round in 2006-7, the third in 2009 and the fourth round in 2013-14. We use data from the young cohort to ensure that we have panel data available for children (younger than 15) over the sample period. The second round of the Young Lives surveys started collecting information on child work. ${ }^{4}$

Our empirical model addresses whether children enter or exit work with dummy variables equal to one if the child undertakes at least one hour a week of agricultural work, nonagricultural work, or household chores. We examine work intensity with the number of hours that a child spends on each activity. The questionnaire asks respondents to recall over a two-week period leading to the interview.

Daily hours of child labor are reported according to the following categories: paid work outside the household including working in factories; unpaid work for the household

\footnotetext{
${ }^{3}$ Rainfall data is available for the period 1950-2014. We use 15-year rainfall average because expanding the period results in missing / unreliable information. Robustness tests using longer-period averages give consistent results.

${ }^{4}$ We only focus on children in rural areas. Unfortunately, the Young Lives Project does not ask households their main source of income, so we are unable to separate farm households from nonfarm households. However, nonfarm households often send their children to work in agriculture. This is particularly true for rural Vietnam, where agriculture is the most common activity.
} 
including agricultural activities (family farm, cattle herding or shepherding); and other family business such as making and selling handicrafts/piece work. The survey also includes information on doing domestic chores such as fetching water, cleaning, cooking, washing, or shopping. All measurements of child labor used in this project are reported by the caregiver. The Young Lives Project collected information on child labor and other characteristics between September and November, which coincides with crop harvesting in Vietnam. Figure 2 provides a summary of child labor (measured using the dummy variable approach) by province in the Young Live sample.

[Figure 2 here]

\section{EMPIRICAL APPROACH}

We estimate a fixed-effect model of the following form:

$$
C L_{i, t}^{j}=\alpha_{0}+\alpha_{1} R D_{i, t}+\alpha_{2} H h_{i, t}+\alpha_{3} C h_{i, t}+\mu_{i}+\gamma_{t}+\varepsilon_{i, t},
$$

where $C L_{i, t}^{j}$ is either a dummy variable equal to one if child $i$ in year $t$ works in type of labor $j$ or the amount of time that a working child spends on each activity. This approach captures exogenous shocks affecting both entrance into employment as well as time spent in employment.

The variable $H h_{i, t}$ is a vector of household characteristics, which includes years of mother's education, number of children in the household, and household wealth. ${ }^{5}$ The variable $C h_{i, t}$ is a vector of time-varying child characteristics, namely age. Following convention in the literature, to avoid the inclusion of a potentially endogenous regressor we focus solely on children that are enrolled in school-85\% of children are enrolled (O’Donnell, Rosati, and Doorslaer 2005; Wolff and Maliki 2008; Beegle, Dehejia, and Gatti 2009; Emerson and Souza 2011). Equation (2) also includes child fixed effects $\left(\mu_{i}\right)$ to capture unobservable time-invariant characteristics of children such as the stock of health or innate ability. Additionally, given that children in the sample do not move across countries or

\footnotetext{
${ }^{5}$ Unfortunately, the Young Lives Project does not collect information on household income. We substitute this variable with a wealth index which consists of three components: housing quality, housing consumption, and housing services.
} 
provinces, child fixed effects also capture time-invariant institutional, cultural, and geographic characteristics that can influence child labor choices within communes. The equation also includes time fixed effects $\left(\gamma_{t}\right)$ to capture covariate time-variant shocks that may influence the probability and incidence of child labor. In the empirical model, we cluster standard errors at the commune level.

In Equation (2), regressions with binary dependent variables are estimated using both panel logit and linear probability models. Both estimation strategies include child-level fixed effects. ${ }^{6}$ Fixed-effects models depend on the presence of variation within each higher-level unit of analysis. ${ }^{7}$ Given that approximately $40 \%$ of children exhibit variation in work status, the number of observations available in regression analysis can be small. Regressions on the amount of time that children work on various activities focus solely on children that are engaged in that activity. In that sense, the paper aims to uncover both entrance into an activity as well as the intensity of the activity amongst those children that work. Table 1 provides summary statistics for the main variables used in the analysis. ${ }^{8}$

\section{[Table 1 here]}

\section{RESULTS AND DISCUSSION}

Table 2 presents the results of the logit and linear probability model (LPM) regressions with child fixed effects. The LPM results provide an approximation of the magnitude of the relationship between rainfall deviation and the probability of entering child labor. Columns (1)-(3) show the logit results, with columns (4)-(6) highlighting their LPM counterparts. For ease of exposition, we only include the coefficient estimates associated with rainfall

\footnotetext{
${ }^{6}$ The results tables show coefficient estimates, not marginal effects. We decide not to use marginal effects because these are calculated under the assumption that all fixed effects are zero in logit models

${ }^{7}$ Positive (negative) values of the coefficient estimates are interpreted as being associated with the probability of entrance (exit) of a given child into a type of work.

${ }^{8}$ We base our summary statistics on the number of observations used in the regression model with the largest number of observations, using the variable 'chores' as the dependent variable. The number of observations used in the regressions is naturally lower than in the original sample because respondents did not necessarily respond to all questions. If respondents answered with 'not applicable” or “don't know," they are treated as missing in our sample. This is not, therefore, due to attrition. We do not include the first round of data since child labor questions were not asked. Gender is not included in the table because it is time invariant. We analyze the results by gender in robustness tests.
} 
deviation. All regressions include the controls discussed in the previous section. Panel A of the table shows the results for both boys and girls, while panels B and C show the results for only girls and boys, respectively.

The logit regression results show a positive and significant relationship between rainfall deviation and the probability that a child engages in agricultural production. The results reveal little difference in the findings by gender. Intuitively, households experiencing more rainfall are likely to benefit positively in terms of agricultural output and will require additional labor during harvesting periods. The table also shows that rainfall deviation does not have a statistically significant effect on the remaining dependent variables.

The LPM results suggest that if rainfall is about $10 \mathrm{~mm}$ (about one standard deviation) above its historical average, the probability that a child enters agriculture increases by $1.2 \%$. Panels B and C suggests that this effect is stronger for boys than girls - if rainfall is $10 \mathrm{~mm}$ above the average, boys experience an increase in the probability of entering agricultural work by $1.7 \%$, while girls experience an increase of about $0.8 \%$. Panel A also suggests that boys and girls are more likely to be undertaking chores - if rainfall is about $10 \mathrm{~mm}$ above its historical average, the probability that a child begins undertaking chores increases by approximately $0.4 \%$, ceteris paribus. In all instances, these effects are small.

\section{[Table 2 here]}

The regressions above test the probability of a child entering work in the aftermath of a rainfall shock. However, this approach ignores the fact that "work" is a multifaceted phenomenon comprised of both undertaking work and its intensity. To measure work intensity, we use a variable that captures the number of hours in the last 14 days that a working child spent on work. We run regressions to capture the relationship between shocks and the amount of time that children dedicate to work.

We present two sets of results that use work hours as the dependent variable in Table 3. Columns (1)-(3) apply fixed effects models to a subsample of children that work, thus restricting the sample significantly. These columns, therefore, potentially suffer from sample selection bias. We address this potential problem in columns (4)-(6) with a correlated random effects (CRE) Tobit model as proposed in Wooldridge (2019). The Tobit model accounts for the large number of children that are not engaged in any type of child labor without having to 
restrict the sample to only working children. The CRE version of the Tobit model is employed as an alternative to fixed effects given that the likelihood estimator for fixed effects is biased and inconsistent in nonlinear models, such as Tobit. CRE models provide within estimates, analogous to fixed effects, by subtracting the cluster mean of time-variant variables in a random effects model (Schunck 2013). Overall, therefore, columns (1)-(3) focus solely on working children, while columns (4)-(6) account for sample selection issues.

Panel A, columns (1)-(3), in Table 3 reveal that above-average rainfall is associated with an increase in the number of hours that working children spend on agriculture and chores, and a decrease in the amount of time that they spend on nonagricultural work. It is relevant to highlight that the magnitude of the effect of the weather shock on hours of work is small—if rainfall is about $10 \mathrm{~mm}$ above its historical average, then agricultural work can increase by 41 additional minutes a week. ${ }^{9}$ A similar change in rainfall is associated with a decrease in nonagricultural work by over 15 minutes and an increase in chores by approximately the same amount. Overall, this suggests that households experiencing more rainfall ask working children to substitute nonagricultural work with chores and agricultural work.

When the sample is disaggregated into girls and boys (panels B and C, columns 1-3), the findings reveal that rainfall deviations are positively associated with changes in the number of hours that girls undertake chores. As for boys, we find evidence that rainfall deviations are associated with fewer hours doing nonagricultural activities, suggesting a certain degree of substitution between agricultural and nonagricultural activities; the coefficient estimate attached to boys' work in agriculture is positive and marginally insignificant $(p$-value $=0.13)$.

The Tobit results in columns (4)-(6) in Table 3 suggest that rainfall deviation is associated with an increase in the number of hours that children undertake chores. In this case, all coefficient estimates in column (6) are statistically significant; column (3) shows a marginally insignificant relationship for boys. Overall, this suggests that rainfall shocks are associated with both an increase in entrance into and time doing household chores. Regarding

\footnotetext{
${ }^{9}$ The coefficient estimates measure changes in fractions of minutes. They can be converted to minutes by multiplying by 60 .
} 
hours in agriculture, however, we find evidence to suggest that sample selection is potentially leading to a positive bias of the results. That is, these columns find no evidence that rainfall variation is increasing the number of hours that children spend doing agricultural work.

[Table 3 here]

To further examine the sensitivity of our results, several other models were estimated. It is possible that smaller deviations in weather result in different labor impacts than larger deviations. For example, very large weather shocks that lead to droughts or floods could potentially pull all workers out of agriculture. If this is the case, then children could be pulled into other activities, including household chores and nonagricultural work. One way to test for this is to introduce the square of rainfall deviation in equation (2). The results of this exercise, available upon request, do not exhibit any evidence of a nonlinear relationship.

An alternative approach is to introduce dummy variables capturing more extreme weather events in the model. Extreme rain is defined as a dummy variable equal to one if actual rainfall is greater than one standard deviation above average rainfall for each commune. Additionally, we construct a drought dummy variable equal to one if actual rainfall is one standard deviation below the average for each commune. We do not obtain significant results with the exception that a drought is associated with boys spending less time on chores.

Finally, we also looked at what happens when the continuous variable is only positive. The results are consistent with those found above. Mainly, children are more likely to enter agriculture, while those children that work on household chores increase the amount of time that they dedicate to chores. We also undertook a robustness test using a larger sample including children that are not enrolled in school. The results remain robust to this examination.

\section{CONCLUSION}

Using panel data techniques, including child fixed effects, and decomposing child labor into agricultural, nonagricultural work, and household chores, this paper finds that above-average rainfall is associated with an increase in the likelihood that children enter work in Vietnam's 
agricultural sector. Moreover, our analysis suggests that rainfall shocks are associated with children that do chores increasing the number of hours that they spend on this activity. Both agricultural work and household chores are potentially harmful to children. Indeed, as part of both types of activities, children could be handling toxic chemicals, carrying heavy loads, handling dangerous sharp items. This suggests that intra-household experiences of exogenous weather shocks are likely to be different, requiring tailored policy responses.

It is important to note that in all occasions we find evidence that children's time is relatively inelastic. That is, relatively large (one standard deviation) shocks are associated with small changes in entrance into work as well as time doing work. 


\section{REFERENCES}

Basu, Kaushik, and Pham Hoang Van. 1998. "The Economics of Child Labor.” American Economic Review 88, no. 3: 412-27.

Beegle, Kathleen; Rajeev H. Dehejia; and Roberta Gatti. 2006. “Child Labor and Agricultural Shocks.” Journal of Development Economics 81, no. 1: 80-96. . 2009. "Why Should We Care about Child Labor? The Education, Labor Market, and Health Consequences of Child Labor.” Journal of Human Resources 44, no. 4: 871-89.

Boozer, Michael A., and Tavneet Suri. 2001. "Child Labor and Schooling Decisions in Ghana.” Unpublished manuscript. https://economics.yale.edu/sites/default/files/files /Workshops-Seminars/Labor-Public/boozer-suri-011005.pdf

Colmer, Jonathan. 2013. “Climate Variability, Child Labour and Schooling: Evidence on the Intensive and Extensive Margin.” FEEM Working Paper no. 81. Milan: Fondazione Eni Enrico Mattei.

Dammert, Ana C. 2008. "Child Labor and Schooling Response to Changes in Coca Production in Rural Peru.” Journal of Development Economics 86, no. 1: 164-80.

Deschênes, Olivier, and Michael Greenstone. 2007. “The Economic Impacts of Climate Change: Evidence from Agricultural Output and Random Fluctuations in Weather.” American Economic Review 97, no. 1: 354-85.

Emerson, Patrick M., and André Portela Souza. (2011). Is child labor harmful? The impact of working earlier in life on adult earnings. Economic Development and Cultural Change, 59(2), 345-385.

Gubert, Flore, and Anne-Sophie Robilliard. 2008. "Risk and Schooling Decisions in Rural Madagascar: A Panel Data-Analysis. Journal of African Economies 17, no. 2: 207-38.

ILO. 2015. World Report on Child Labour 2015: Paving the Way to Decent Work for Young People. Geneve: ILO. 
- 2018. "Child Labour and Domestic Work (IPEC)." http://www.ilo.org/ipec/areas/Childdomesticlabour/lang--en/index.htm ～(accessed February 1, 2019)

Mendelsohn, Robert; William D. Nordhaus; and Daigee Shaw. 1994. "The Impact of Global Warming on Agriculture: A Ricardian Analysis.” American Economic Review 84, no. 4: 753-71.

O’Donnell, Owen; Furio C. Rosati; and Eddy Van Doorslaer. 2005. "Health Effects of Child Work: Evidence from Rural Vietnam.” Journal of Population Economics 18, no. 3: 437-67.

Schunck, Reinhard. 2013. "Within and Between Estimates in Random-Effects Models: Advantages and Drawbacks of Correlated Random Effects and Hybrid Models.” Stata Journal 13, no. 1: 65-76.

Trinh, Tong Anh. 2017. "The Impact of Climate Change on Agriculture: Findings from Households in Vietnam.” Environmental and Resource Economics 71, no. 4: 897921.

Wolff, François-Charles, and Maliki. 2008. "Evidence on the Impact of Child Labor on Child Health in Indonesia, 1993-2000.” Economics \& Human Biology 6, no. 1: 143-69.

Wooldridge, Jeffrey M. 2019. “Correlated Random Effects Models with Unbalanced Panels.” Journal of Econometrics 211, no. 1: 137-50.

World Bank. 2010. Economics of Adaptation to Climate Change-Synthesis Report. Washington DC: World Bank. 


\section{TABLE 1}

\section{Summary Statistics}

\begin{tabular}{lccrrr}
\hline Variable & Obs. & Mean & Std. Dev. & Min & Max \\
\hline Child in agricultural work (dummy variable) & 2,374 & 0.10 & 0.29 & 0 & 1 \\
Hours of child work in agriculture & 2,373 & 0.17 & 0.62 & 0 & 6 \\
Child in nonagricultural work (dummy variable) & 2,358 & 0.10 & 0.30 & 0 & 1 \\
Hours of child work in nonagriculture & 2,358 & 0.02 & 0.20 & 0 & 3 \\
Child does chores (dummy variable) & 2,374 & 0.51 & 0.50 & 0 & 1 \\
Hours of chores that child does & 2,374 & 0.68 & 0.81 & 0 & 5 \\
Rainfall deviation (in millimeter) & 2,374 & 5.90 & 6.67 & -16.78 & 16.33 \\
Age (in years) & 2,374 & 8.80 & 2.79 & 4.69 & 13.17 \\
Mother's years of education (in years) & 2,374 & 6.48 & 3.18 & 0 & 12 \\
No. of children & 2,374 & 0.36 & 0.55 & 0 & 4 \\
Wealth index & 2,374 & 0.55 & 0.15 & 0.02 & 0.94 \\
\hline
\end{tabular}


TABLE 2

Impact of Above-Average Rainfall on Entrance into Child Labor (logit fixed-effects)

\begin{tabular}{|c|c|c|c|c|c|c|}
\hline & \multicolumn{6}{|c|}{ Dependent Variable: Child Labor in Each Work } \\
\hline & \multicolumn{3}{|c|}{ Logit FE } & \multicolumn{3}{|c|}{ LPM-FE } \\
\hline & $\begin{array}{c}\text { Agriculture } \\
(1)\end{array}$ & $\begin{array}{c}\text { Nonagriculture } \\
\text { (2) }\end{array}$ & $\begin{array}{c}\text { Chores } \\
(3)\end{array}$ & $\begin{array}{c}\text { Agriculture } \\
\text { (4) }\end{array}$ & $\begin{array}{l}\text { Nonagriculture } \\
\text { (5) }\end{array}$ & $\begin{array}{l}\text { Chores } \\
(6)\end{array}$ \\
\hline \multicolumn{7}{|l|}{ A. All } \\
\hline Rainfall deviation & $\begin{array}{l}0.12 * * * \\
(2.80)\end{array}$ & $\begin{array}{c}0.013 \\
(0.57)\end{array}$ & $\begin{array}{l}0.023 \\
(1.22)\end{array}$ & $\begin{array}{l}0.012^{* * *} \\
(3.32)\end{array}$ & $\begin{array}{l}0.0037 \\
(0.70)\end{array}$ & $\begin{array}{l}0.0039 * \\
(1.86)\end{array}$ \\
\hline Observations & 680 & 699 & 2,374 & 680 & 699 & 2,374 \\
\hline$R^{2}$ & 0.69 & 0.36 & 0.69 & 0.69 & 0.31 & 0.58 \\
\hline \multicolumn{7}{|l|}{ B. Girls } \\
\hline Rainfall deviation & $\begin{array}{l}0.12 * \\
(1.66)\end{array}$ & $\begin{array}{r}0.012 \\
(0.43)\end{array}$ & $\begin{array}{l}0.019 \\
(0.72)\end{array}$ & $\begin{array}{l}0.0077 * \\
(1.74)\end{array}$ & $\begin{array}{l}0.0035 \\
(0.53)\end{array}$ & $\begin{array}{l}0.0032 \\
(1.14)\end{array}$ \\
\hline Observations & 319 & 398 & 1,178 & 319 & 398 & 1,178 \\
\hline$R^{2}$ & 0.70 & 0.35 & 0.68 & 0.73 & 0.30 & 0.58 \\
\hline \multicolumn{7}{|l|}{ C. Boys } \\
\hline Rainfall deviation & $\begin{array}{l}0.13^{* *} \\
(2.26)\end{array}$ & $\begin{array}{r}0.020 \\
(0.55)\end{array}$ & $\begin{array}{l}0.030 \\
(1.13)\end{array}$ & $\begin{array}{l}0.017 * * * \\
(3.03)\end{array}$ & $\begin{array}{l}0.0041 \\
(0.47)\end{array}$ & $\begin{array}{l}0.0049 \\
(1.57)\end{array}$ \\
\hline Observations & 361 & 301 & 1,196 & 361 & 301 & 1,196 \\
\hline$R^{2}$ & 0.69 & 0.38 & 0.70 & 0.67 & 0.34 & 0.59 \\
\hline
\end{tabular}

Note: Summary of regression results presented. All controls, including child fixed effects, are employed. Z-statistics in parentheses.

$* * * p<0.01, * * p<0.05, * p<0.1$. 
TABLE 3

Child Labor Hours and Rainfall Deviation

\begin{tabular}{|c|c|c|c|c|c|c|}
\hline & \multicolumn{6}{|c|}{ Dependent Variable: Child Labor Hours in Each Work } \\
\hline & \multicolumn{3}{|c|}{ FE (Limited samples) } & \multicolumn{3}{|c|}{ CRE Tobit (All samples) } \\
\hline & $\begin{array}{l}\text { Agriculture } \\
\text { (1) }\end{array}$ & $\begin{array}{l}\text { Nonagriculture } \\
\text { (2) }\end{array}$ & $\begin{array}{l}\text { Chores } \\
\text { (3) }\end{array}$ & $\begin{array}{c}\text { Agriculture } \\
\text { (4) }\end{array}$ & $\begin{array}{c}\text { Nonagriculture } \\
\text { (5) }\end{array}$ & $\begin{array}{c}\text { Chores } \\
(6)\end{array}$ \\
\hline \multicolumn{7}{|l|}{ A. All } \\
\hline Rainfall deviation & $\begin{array}{l}0.069 * \\
(1.89)\end{array}$ & $\begin{array}{l}-0.027 * \\
(-1.76)\end{array}$ & $\begin{array}{l}0.023^{* * *} \\
(3.39)\end{array}$ & $\begin{array}{r}0.028 \\
(1.21)\end{array}$ & $\begin{array}{l}0.017 \\
(0.31)\end{array}$ & $\begin{array}{l}0.076^{* * * *} \\
(14.3)\end{array}$ \\
\hline Observations & 342 & 331 & 1,628 & 3,318 & 3,291 & 3,321 \\
\hline$R^{2}$ & 0.21 & 0.25 & 0.15 & & & \\
\hline$\chi^{2} p$-value & & & & 0 & 0 & 0 \\
\hline \multicolumn{7}{|l|}{ B. Girls } \\
\hline Rainfall deviation & $\begin{array}{c}0.0020 \\
(0.041)\end{array}$ & $\begin{array}{c}-0.020 \\
(-0.90)\end{array}$ & $\begin{array}{l}0.031^{* * *} \\
(3.17)\end{array}$ & $\begin{array}{c}-0.0035 \\
(-0.12)\end{array}$ & $\begin{array}{c}0.0071 \\
(0.12)\end{array}$ & $\begin{array}{c}0.072 * * * \\
(9.97)\end{array}$ \\
\hline Observations & 152 & 187 & 863 & 1,608 & 1,597 & 1,609 \\
\hline$R^{2}$ & 0.66 & 0.23 & 0.19 & & & \\
\hline$\chi^{2} p$-value & & & & 0 & 0.046 & 0 \\
\hline \multicolumn{7}{|l|}{ C. Boys } \\
\hline Rainfall deviation & $\begin{array}{r}0.064 \\
(1.49)\end{array}$ & $\begin{array}{l}-0.041^{* * *} \\
(-2.96)\end{array}$ & $\begin{array}{c}0.014 \\
(1.53)\end{array}$ & $\begin{array}{r}0.054 \\
(1.63)\end{array}$ & $\begin{array}{r}0.023 \\
(0.23)\end{array}$ & $\begin{array}{c}0.079 * * * \\
(10.2)\end{array}$ \\
\hline Observations & 190 & 144 & 765 & 1,710 & 1,694 & 1,712 \\
\hline$R^{2}$ & 0.16 & 0.58 & 0.10 & & & \\
\hline$\chi^{2} p$-value & & & & 0 & 0.081 & 0 \\
\hline
\end{tabular}

Note: Summary of regression results presented. All controls, including child fixed effects, are employed. Robust $t$-statistics in parentheses.

$* * * p<0.01, * * p<0.05, * p<0.1$. 
Fig. 1. Rainfall Deviation per Province, 2002-14

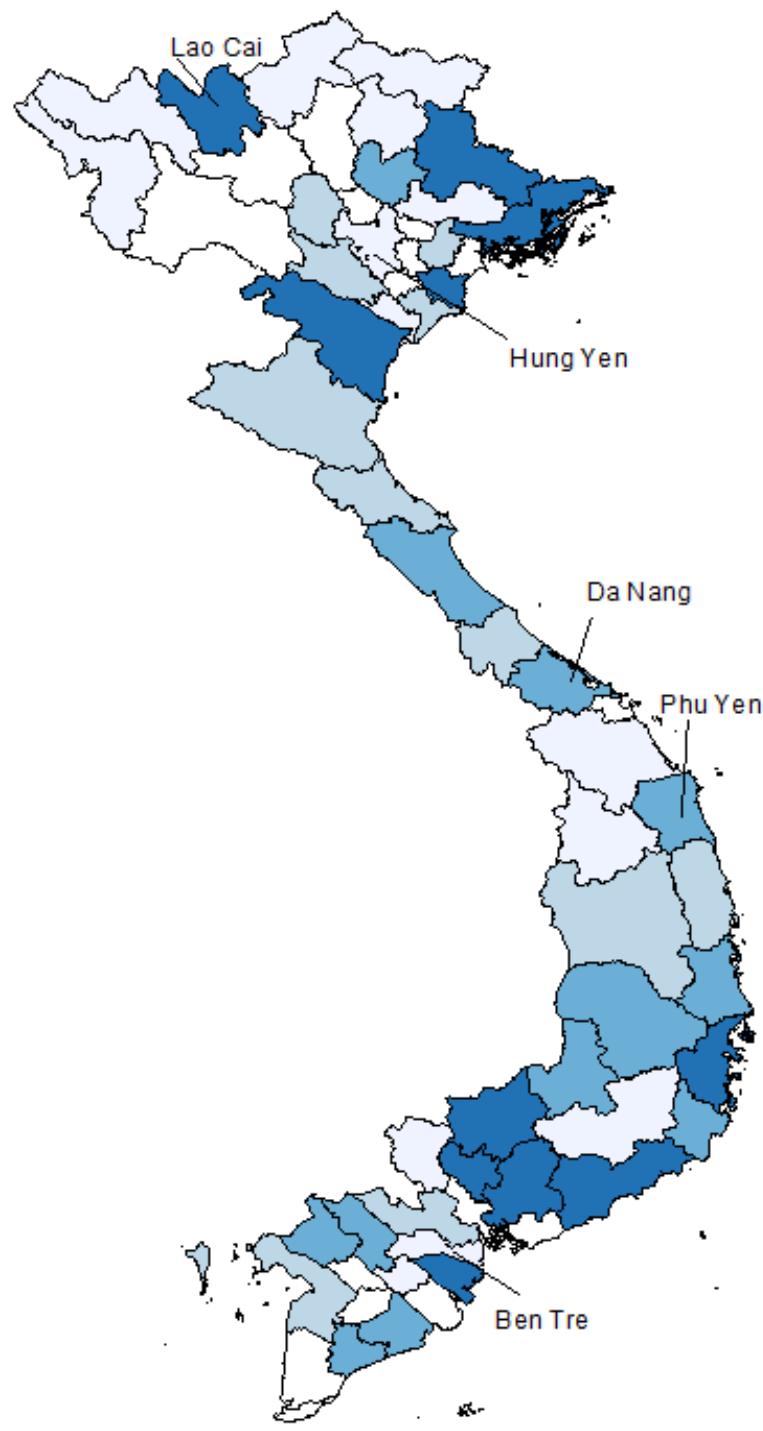

Source: Authors' calculation from the rainfall data.

Notes: A darker value represents a higher deviation of rainfall. 


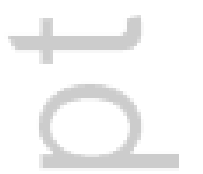

This article is protected by copyright. All rights reserved. 
Fig. 2. Proportion of Child Labor per Province, 2009 (\%)

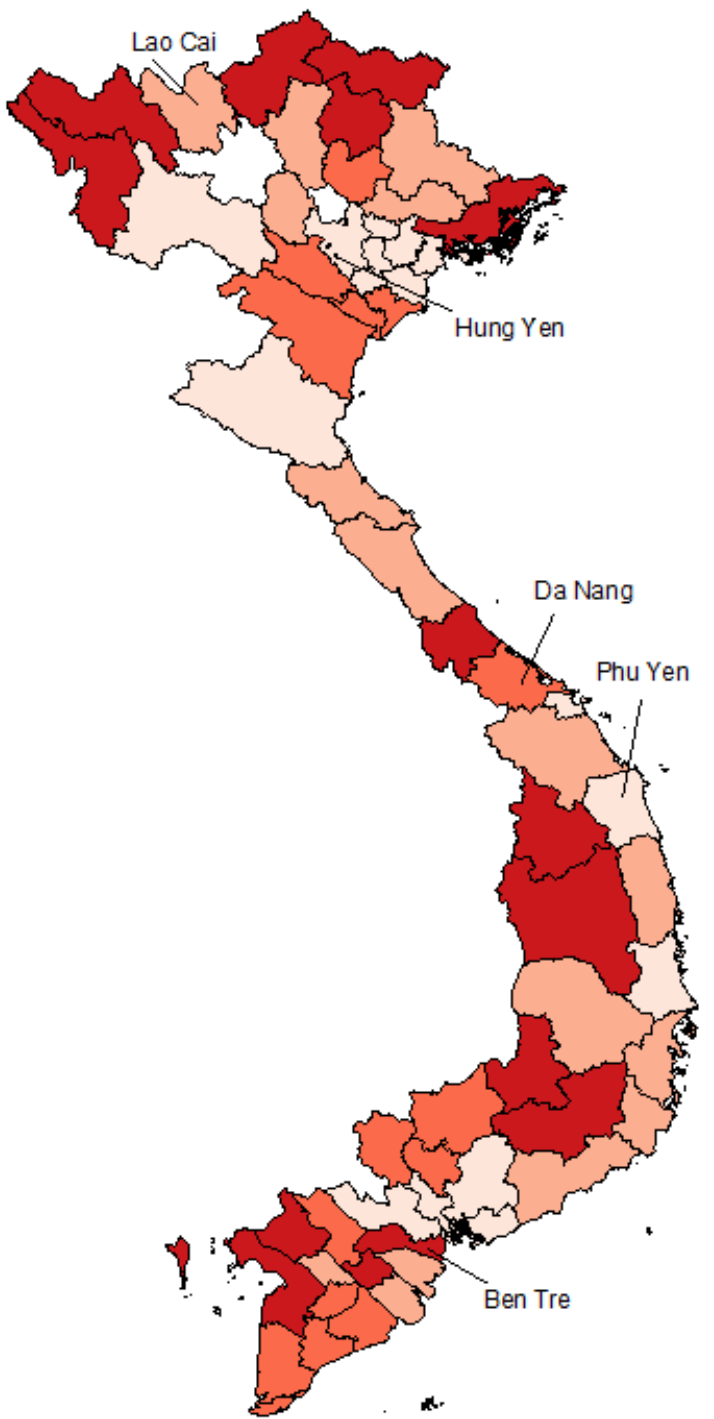

Source: Authors’ calculation from the Vietnam Population and Housing Census 2009. Note: A darker value represents a higher proportion of child labor. 


\section{University Library}

\section{- M M I N E R VA A gateway to Melbourne's research publications}

Minerva Access is the Institutional Repository of The University of Melbourne

Author/s:

Trinh, T-A;Posso, A;Feeny, S

Title:

Child Labor and Rainfall Deviation: Panel Data Evidence from Rural Vietnam

Date:

2020-03-01

Citation:

Trinh, T. -A., Posso, A. \& Feeny, S. (2020). Child Labor and Rainfall Deviation: Panel Data Evidence from Rural Vietnam. DEVELOPING ECONOMIES, 58 (1), pp.63-76. https:// doi.org/10.1111/deve.12215.

Persistent Link:

http://hdl.handle.net/11343/286922 